\title{
Simulation Model of Solar Induction Motor Drive System Using SVPWM Technique
}

\author{
K. Geetha, C. Preethy and P. Thenmozhi
}

\begin{abstract}
Economic development of a country depends upon the basic resources available. The overall economic growth and development of a country of the energy, Solar energy based vitality is a fabulous wellspring of renewable vitality. This proposed work means to configure, reproduce and examine a photovoltaic controlled miniaturized scale inverter to encourage an enlistment engine. The miniaturized scale inverter incorporates a high stride up converter and a three stage inverter. The high stride up DC-DC converter is furnished with a Maximum Power Point Tracker (MPPT) framework obliged voltage to accomplish most extreme power. Three stage voltage source inverter is utilized to change over $D C$ voltage to AC voltage. An enlistment engine is associated at the yield of this framework. To get a better engine execution, to diminish bring down sounds which can't be disposed of by channels. These musics can be disposed of by the by utilizing Space vector Pulse Width Modulation (SVPWM) strategy. Tangle lab/SIMULINK is utilized to mimic and to research the conduct of the proposed framework.
\end{abstract}

Keywords--- Induction Motor, SVPWM, Solar Energy, MPPT, LC Filter.

\section{INTRODUCTION}

OLAR energy is the lowest price, struggle free, universal $\checkmark$ source of energy as the sun shines throughout. This energy can be changed into useful electrical energy using photovoltaic machinery. The steady state drop of price per peak watt and minimalism with which the installed power can be increased by adding panels are attractive features of PV technology [1]. A solar inverter or Photo voltaic inverter converts the variable direct current output of a photo voltaic solar panel into a utility frequency alternating current that can be fed into a commercial electrical grid or used by local off grid electrical network [2]. It is a critical component in a photovoltaic system.

As we know the current global energy crisis is very high, so we have to go with renewable energy. In the block diagram used a PV cell as a DC input source. Photovoltaic (PV) solar energy is one of the green energy sources which can play an important role in reducing greenhouse gas emissions, and global warming, among various renewable energy sources. The PV cell converts solar radiation to direct current electricity using semiconductor devices that exhibit the photovoltaic effect. The solar cell works in three steps:

K. Geetha, PG Scholar, ST.Joseph's College of Engineering, Chennai.

C. Preethy, PG Scholar, ST.Joseph's College of Engineering, Chennai.

P. Thenmozhi, PG Scholar, ST.Joseph's College of Engineering, Chennai. DOI : 10.9756/BIJPSIC.8312
1. Photons in sunlight hit the solar panel and are absorbed by semiconducting materials, such as silicon.

2. Electrons (negatively charged) are knocked loose from their atoms, causing an electric potential difference. Current starts flowing through the material to cancel the potential and this electricity are captured. Due to the special composition of solar cells, the electrons are only allowed to move in a single direction.

3. An array of solar cells converts solar energy into a usable amount of direct current (DC) electricity.

The most important feature required for a well-designed PWM technique is that it should not allow different phases to switch simultaneously. SVPWM is the only PWM technique which satisfies the above condition. Compared to conventional SVPWM among the eight possible switching states in which two of them are zero vectors and six of them are active switching states, the conventional zero vectors are eliminated in each sector in Space vector pulse width amplitude modulation technique. Thus, the brief will be having its maximum amplitude. Thus SVPWAM method is a combination of amplitude modulation and pulse width modulation such that each inverter leg is switched during one third of fundamental period.

\section{LITERATURE REVIEW}

D. Venkata Anil Sai Ram, B Venkata Ramana, 2014. In this paper PI controller is utilized to diminish the unfaltering state mistake without change in security. The Greatest power from photovoltaic is extricated by utilizing an MPPT calculation (consistent voltage strategy). In this paper, to modify the engine speed to a set point Closed circle speed controller is embraced. Additionally, reenactment results are examined and broke down [3]. PV cluster is the blend of psort and no-sort semiconductors. It straightforwardly changes over daylight into electrical vitality. Photons from the daylight are consumed by the PV material to deliver electrical vitality, when sun powered vitality surpasses the band-crevice vitality of the PV module. The sun oriented cells in PV framework are tied in arrangement or parallel contingent on necessity and the delivered electrical vitality of the PV module relies on the board temperature, sun based ordinance, working current and voltage relationship i.e. the V-I normal for the PV cluster is a non-direct and complex capacity.

Dr. T. Govindaraj, Sreema. R.S, 2014. In this paper the Module Inverter structure is a two-stage system. The first stage is a high step-up high-efficiency DC-DC converter with maximum power point tracking control. The DC-DC converter raises the input low voltage to a high voltage level. The maximum power point tracking is used to extract maximum 
power from the photo voltaic module. The second stage is a full-bridge inverter [4]. The DC-AC inverter transforms DC voltage from the first stage into the sinusoidal voltage waveform. Maximum power point tracking algorithm which uses a hill climbs method.

K. R. Sasitharan, Dr. K. Ranjith Kumar, 2014 In this paper, to utilize the electric energy produced by the PV array is to deliver it to the AC mains directly, without using battery storage. The absence of fuel cost, noise, pollution the solar energy source is used for renewable energy among all other sources. The maintenance cost less. However, the PV system has low efficiency due irradiation and temperature. To improve the efficiency of PV system, Maximum Power Point Tracking (MPPT) has been developed such as P\&O, Constant Voltage and so on. Previously DC source will be a supply and power to quasi-Z-source inverter with RL load. In this paper solar panel will be an input source to quasi-Z-source inverter with MPPT P\&O Techniques with Induction motor have been simulated [5].

K. B. Rohit, Prof. G. M. Karve, Prof. Khatri, 2013 This paper investigates the design, modelling and simulation of a photovoltaic powered motor drive for pump irrigation application. A number of experimental Photovoltaic [PV] powered DC motor drives for pump and irrigation purposes are already in use, however such schemes find limited applications due to high cost and maintenance problems commonly associated with DC commutator type machines [6].

Dr. Rashmi, Rajesh K, S, Manohar J, Darshini C, 2016 The paper deals with the study of an Induction Motor drive system integrating Push-Pull Converter and three phase inverter using a single solar photovoltaic panel. To step-up the voltage from the panel to drive motor a push-pull converter is used. To obtain better motor performance, to reduce the harmonic content of the inverter output waveform and to increase the efficiency of the system, we use Space Vector Pulse Width Modulation (SVPWM) Technique for inverter switching [7].

\section{PROPOSED SYSTEM}

The block diagram of the proposed system is shown in Fig.1. The block diagram mainly consists of PV panel, high step up converter, three Phase Inverter and Induction Motor. The PV panels mainly consist of cells, which are connected in series or parallel and the electrical power from the panel mainly depends on the solar irradiance, panel temperature and operating current and voltage relationship. The I-V characteristics of PV array, is complex and nonlinear function.

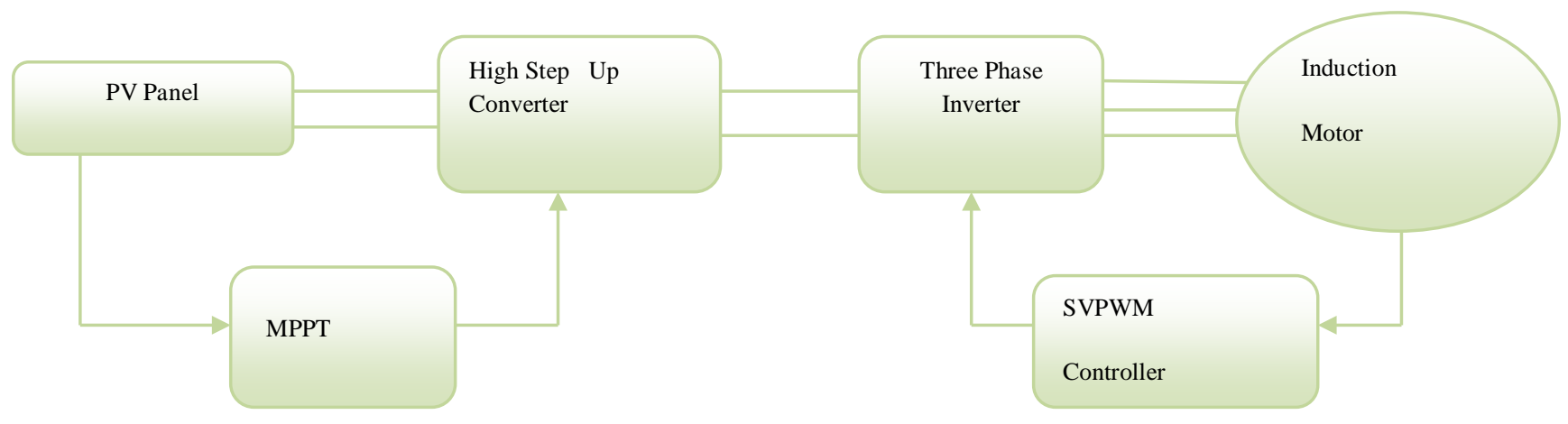

Fig. 1: Block Diagram of the Proposed System

Maximum power point tracking technique is used to extract maximum power from the panel. Since, it minimizes the solar array price by reducing the number of solar modules required to get the preferred output power. Due to variation in climate there will be changes in the power from the board. Hence, MPPT Techniques are used to gain more power from the panel. SVPWM is employed to generate the desired output voltage vector V in d-q reference frame. For a three phase VSI there are totally eight possible switching patterns and each of them determines a voltage space vector. The models have been done in SVPWM technique using Matlab/Simulink. Inverter output phase voltage, line voltages and load line voltages and phased currents are obtained through simulation.

\section{A. PV Panel}

The Solar-PV cells are used to produce electricity by directly converting solar energy to electrical energy. Each solar cell is basically a p-n diode. As sunlight strikes a solar cell, the incident energy is converted directly into electrical energy without any mechanical effort. The voltage and current levels are produced from PV cells are very less, thus these PV cells are connected in series and parallel called modules and arrays to produce required voltage and current levels. The solar PV array is modeled by considering the output characteristics of PV panel, which directly have relation with power converters which exists in the system.

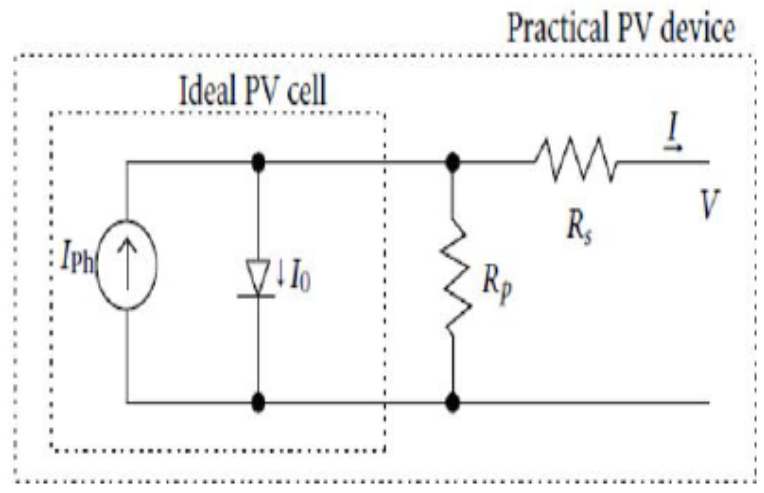

Fig. 2: PV Cell Model 


\section{B. High Step Up Converter}

A step-up converter is a DC-to-DC power converter with an output voltage greater than its input voltage. It is a class of switched-mode power supply (SMPS) containing at least two semiconductor switches (a diode and a transistor) and at least one energy storage element, a capacitor, inductor, or the two in combination. Filters made of capacitors (sometimes in combination with inductors) are normally added to the output of the converter to reduce output voltage ripple. Power for the converter can come from any suitable DC sources, such as batteries, solar panels, rectifiers and DC generators. A process that changes one DC voltage to a different DC voltage is called DC to DC conversion. The output voltage has the same polarity as the input voltage.

\section{Three Phase Inverter}

The Inverter is a powerful electronic device, it converts DC to AC. The Inverter generates at any required voltage or frequency by proper switching and control technique. There are single phase and three phase inverters but the three-phase inverters are commonly used in high power applications. This inverter consists of three half-bridge units, the switching devices can be IGBTs, BJTs, GTOs, and etc. the controlling of switches depends on the required power level, desired frequency.When the upper switch turned on the corresponding lower switch should turn off and vice versa. In 3-pH inverters gating pulses are delayed by 120 degrees with respect to each. Six modes of operation are possible for each cycle and has an interval of 60 degrees. Therefore 3-pH voltages lag of 120 degrees. The inverter output is a square waveform when it is not connected to a transformer. This square waveform can be converted to sine waveform by using an LC low pass filter.

\section{Induction Motor}

Induction motor is an electrical to mechanical conversion device and it is an asynchronous AC machine because the rotor speed is always less than the stator magnetic speed. The construction of IM is rugged and cheep therefore it is widely used in many applications like in elevators, water pumping system and in industries. The frequency of the stator voltage controls the synchronous speed. The speed control of IM is possible by controlling the frequency, by changing the number of rotor poles, by changing the slip, by injecting the emf in phase or out of phase with the rotor induced emf etc. in this paper the output of the PV system fed to the boost converter, this converter increase voltage level and fed to 3-pH inverter, SVPWM is used to control the output of the inverter and is fed to induction motor.

\section{E. Space-Vector Pulse Width Modulation (SVPWM)}

The main concept of SVWPM technique is to generate appropriate PWM signals, consequently a vector with any preferred angle can be generated therefore Space-vector PWM (SVPWM) technique is the technique which increases the output voltage. SVPWM was introduced in -1980s. It has become one of the most essential PWM methods for three phase inverter. Several SVPWM schemes have been developed with the development of microprocessors. When compared with the SPWM technique the SVPWM technique effectively utilizes the voltage of DC bus and generates less
THD. SVPWM Peak fundamental magnitude is about $90.6 \%$ of the inverter capacity. When compared with sinusoidal pulse width modulation SVPWM increase the maximum voltage by $15.5 \%$. SVPWM is

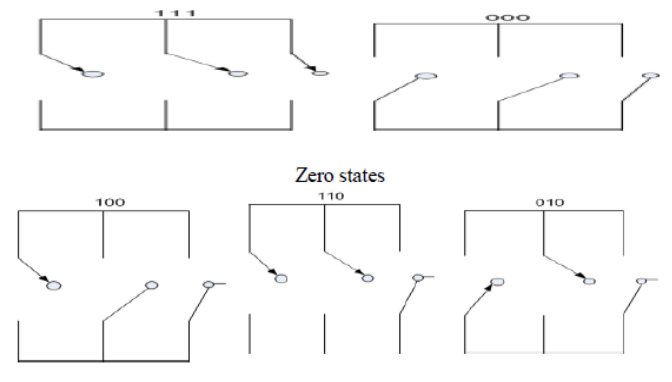

Accomplished by rotating a reference vector around the state diagram, a circle can be formed inside the state map. In the representation of SVPWM there are two regions one region under the circle is called the linear or undermodulation region. There are 8 possible vectors are possible in 2 level inverters. If the top switch is on state $=1$, if the bottom switch is on switch state $=0$. Eight possible states are basing for SVM principle as shown in figure 3 and corresponding state space representation is shown in figure 4.

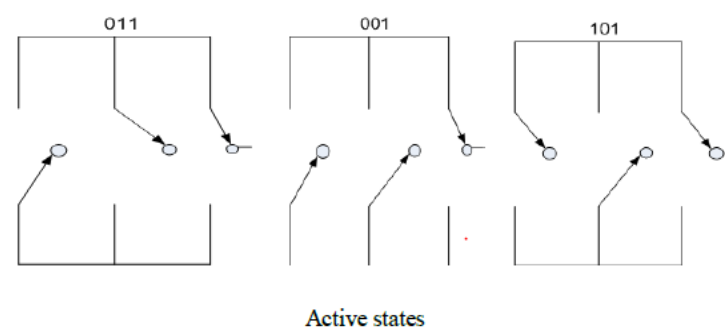

Fig. 3: Switching States

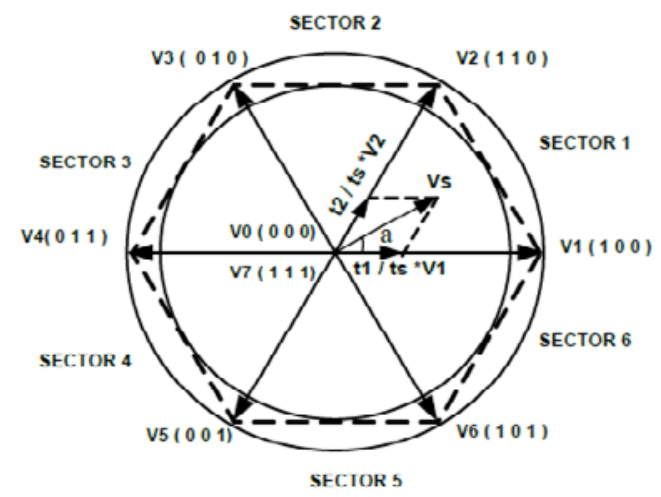

Fig. 4: Space Vector Representation

In the state space representation each sector makes an angle of 600. Zero vectors are placed in the Centre of hexagons and active vectors are located at the edges of the hexagon. Concept of space vector (SV) originates from axestransformation. SV leads to transformation of 3 phase quantities to 2 phase quantities. SVPWM offers better flexibility in terms of switching sequences. Its implementation is computationally complex because it involves so many mathematical calculations and efforts. Steps involved in the development of simulation models are discussed briefly here. 


\section{Three Phases to Two Phase Transformation}

The three phase signals which are displaced by an angle of 1200 are converted into two phase signals. This transformation is shown in Fig. 5

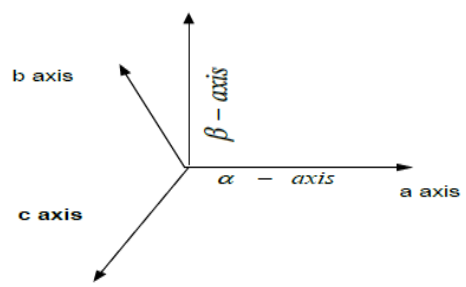

Fig. 5: ABC to $\alpha \beta$ Transformation

Equations corresponding to 3 phase to 2 phase transformation.

$$
\begin{gathered}
\mathrm{V}_{\alpha}=\frac{2}{3}\left[\left(\mathrm{~V}_{\mathrm{a}}\right)-\frac{1}{2}\left(\mathrm{~V}_{\mathrm{b}}+\mathrm{V}_{\mathrm{c}}\right)\right] \\
\mathrm{V}_{\mathrm{B}}=\frac{1}{\sqrt{3}}\left[\mathrm{~V}_{\mathrm{b}}+\mathrm{V}_{\mathrm{c}}\right]
\end{gathered}
$$

\section{Calculation of Angle and Identification of Sector}

Generally space vector hexagon is subdivided into 6 parts. Each part represents a sector, conventionally depending on the angle made by reference vector we can identify the sector number and corresponding calculations can be done. The coefficient of time calculation is given by the equation.

$$
\mathrm{K}=\frac{2}{\sqrt{3}} \frac{V s}{V d c} \mathrm{~T}_{\mathrm{s}}
$$

\section{Calculation of Dwell Times}

For deriving dwell times any one of the sectors should be selected.

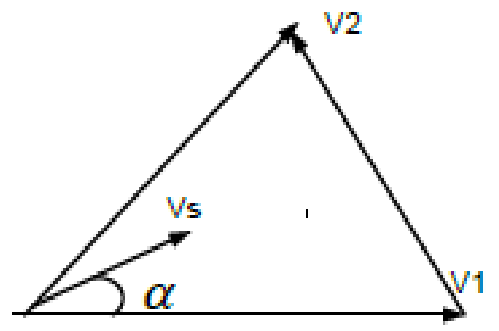

Fig. 6: Sector 1

Along the Axis

$$
\mathrm{V}_{1} \mathrm{~T}_{1}+\mathrm{V}_{2} \mathrm{~T}_{2} \cos 60=\mathrm{V}_{\mathrm{s}} \mathrm{T}_{\mathrm{s}} \cos \alpha
$$

Along the $\beta$ Axis

$$
\mathrm{V}_{2} \mathrm{~T}_{2} \sin 60=\mathrm{V}_{\mathrm{s}} \mathrm{T}_{\mathrm{s}} \sin 60
$$

By solving above equations, expressions obtained for T1 and $\mathrm{T} 2$ are as shown below.

Actually,

$$
\mathrm{T}_{1}=\mathrm{T}_{\mathrm{s}} \frac{V s}{V d c} \frac{2}{\sqrt{3}} \operatorname{Sin} \alpha
$$

From the above equation

$$
\mathrm{T}_{0}+\mathrm{T}_{1}+\mathrm{T}_{2}=\mathrm{T}_{\mathrm{s}}
$$

$$
\mathrm{T}_{0 / 2}=\frac{1}{2}\left[\mathrm{~T}_{\mathrm{s}}-\left(\mathrm{T}_{1}+\mathrm{T}_{2}\right)\right]
$$

Where T1, T2, T0/2 are dwell times. The Same rules can be used for calculation of dwell times in sectors 2 to 6 .

\section{Calculation of Times for Each Switch}

For generating the gate pulses, switching times should be decided. This can be done with the help of the following Table1.

\begin{tabular}{|r|c|c|c|}
\hline \multirow{2}{*}{ sector } & \multicolumn{3}{|c|}{ Upper switches } \\
\cline { 2 - 4 } & $\mathrm{a}$ & $\mathrm{b}$ & $\mathrm{c}$ \\
\hline 1 & $T_{1}+T_{2}+T_{0 / 2}$ & $T_{2}+T_{0 / 2}$ & $T_{0 / 2}$ \\
\hline 2 & $T_{2}+T_{0 / 2}$ & $T_{1}+T_{2}+T_{0 / 2}$ & $T_{0 / 2}$ \\
\hline 3 & $T_{0 / 2}$ & $T_{1}+T_{2}+T_{0 / 2}$ & $T_{2}+T_{0 / 2}$ \\
\hline 4 & $T_{0 / 2}$ & $T_{2}+T_{0 / 2}$ & $T_{1}+T_{2}+T_{0 / 2}$ \\
\hline 5 & $T_{2}+T_{0 / 2}$ & $T_{0 / 2}$ & $T_{1}+T_{2}+T_{0 / 2}$ \\
\hline 6 & $T_{1}+T_{2}+T_{0 / 2}$ & $T_{0 / 2}$ & $T_{2}+T_{0 / 2}$ \\
\hline
\end{tabular}

Once the upper switches switching timings are known it is easy to calculate the lower switches switching times by complementing the upper switching times.

\section{F. Maximum Power Point Tracking (MPPT)}

Maximum power point tracking (MPPT) is a technique that grid connected inverters, solar battery chargers and similar devices use to get the maximum possible power from one or more photovoltaic device, typically solar panels, though optical power transmission systems can benefit from similar technology. Solar cells have a complex relationship between solar irradiation, temperature and total resistance that produces a non-linear output efficiency, which can be analyzed based on the I-V curve. It is the purpose of the MPPT system to sample the output of the cells and apply the proper resistance (load) to obtain maximum power for any given environmental conditions. MPPT devices are typically integrated into an electric power converter system that provides voltage or current conversion, filtering, and regulation of driving various loads, including power grids, batteries, or motors.

\section{Proposed System OF SVPWM TEChNiQUe Using MATLAB/SIMULINK}

The modelling and simulation has been done for SVPWM technique using Matlab/Simulink. Inverter output phase voltage, line voltages and load line voltages and phased currents are obtained through simulation. In the proposed system Induction motor is used because of its wide applications and reasonable cost. A sinusoidal voltage is applied to the stator, in the induction motor which results in an induced electromagnetic field. A current in the rotor is induced due to this field, which creates another field that tries to align with the stator field, causing rotor to spin. A slip is created between these fields, when a load is applied to the motor compared to the synchronous speed, the rotor speed decreases at higher slip values. The frequency of the start voltage controls the synchronous speed. 


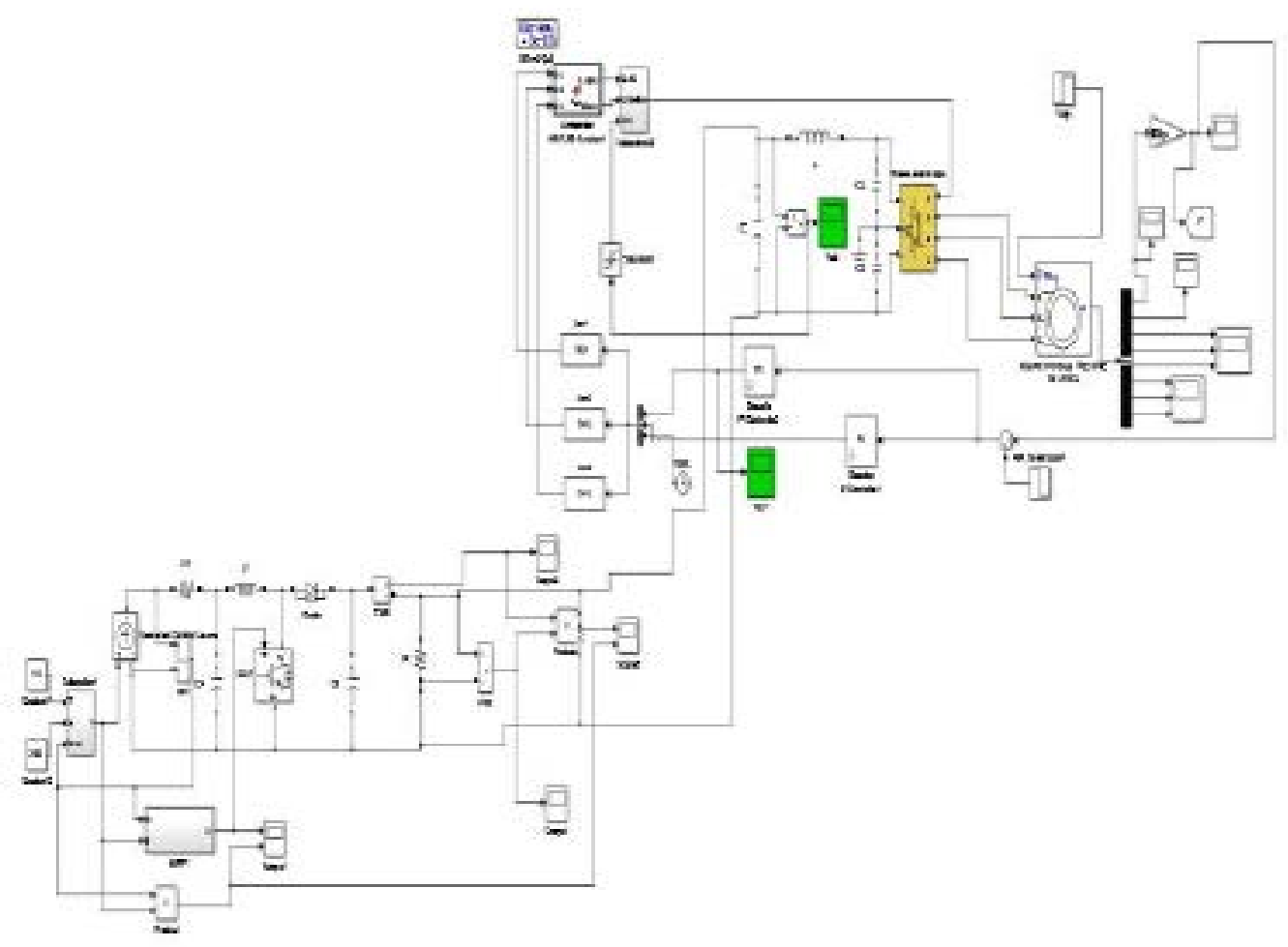

Fig. 7: Simulink Model of SVPWM Technique

\section{ReSUlTS AND DisCUSSION}

Proposed system fed by Solar, is designed and simulated in MATLAB, Simulink environment, and the results are presented in this section.

\section{Specifications of PV System}

Temperature variations range of PV System $(T)=298 \mathrm{~K}$ Irradiance $(\mathrm{G})=1000 \mathrm{~W} / \mathrm{m} 2-900 \mathrm{~W} / \mathrm{m} 2$.

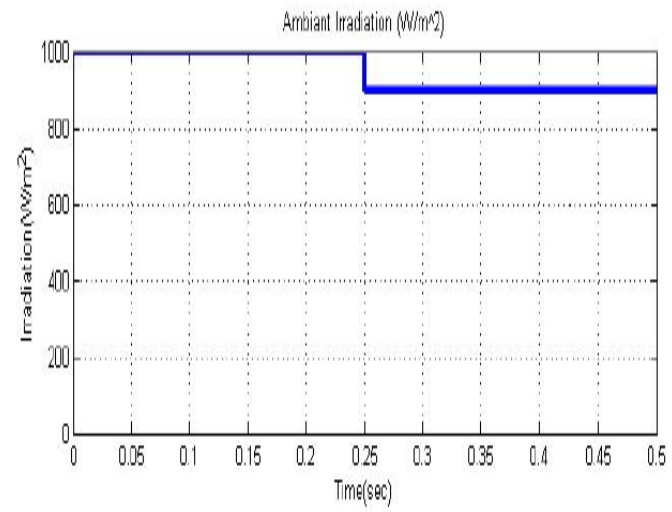

Fig. 8: Ambient Irradiation of Solar PV Module

The output voltage and currents of MPPT based DC-DC converter is fig 9. Additionally, transient parameters of DC-DC converter with MPPT algorithm is calculated with the help of MATLAB Simulink environment and presented in Fig.
10. Fig. 11 represents the voltage of solar PV array which is formed by solar PV module series connection.
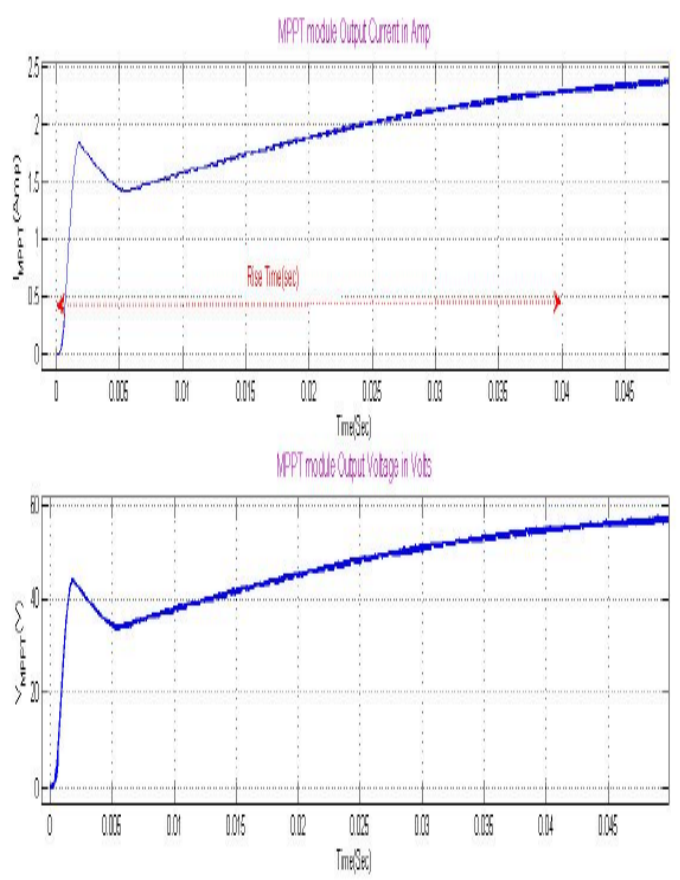

Fig. 9: Module based MPPT DC-DC Converter Parameters 


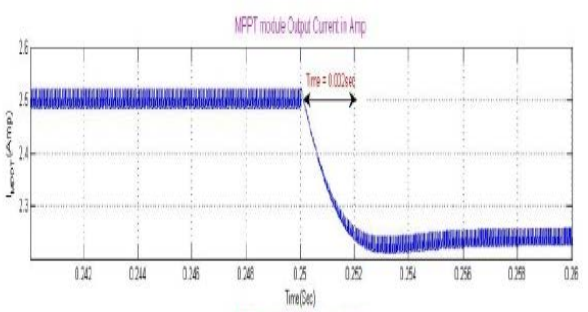

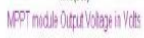

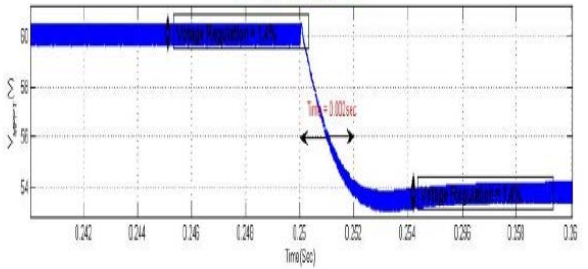

Fig. 10: Module based MPPT DC-DC Converter Parameters during Transient Conditions

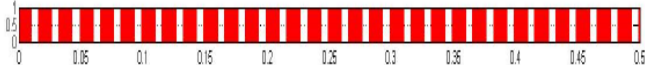

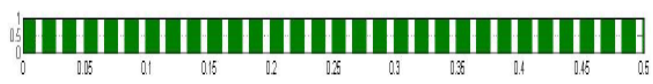

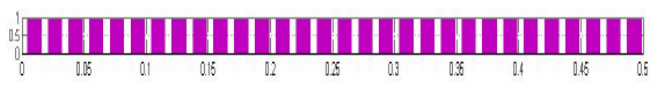

\section{$\prod_{0}^{1} \prod_{015} \prod_{01} \prod_{015} \prod_{02} \prod_{0.5} \prod_{03} \prod_{0.5} \prod_{015} \prod_{0.5}$}
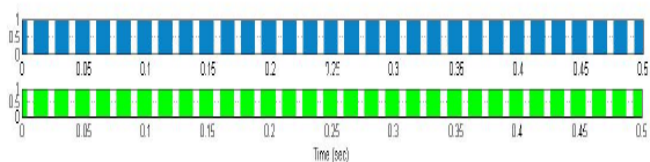

Fig. 11: SVPWM based Pulse Signals

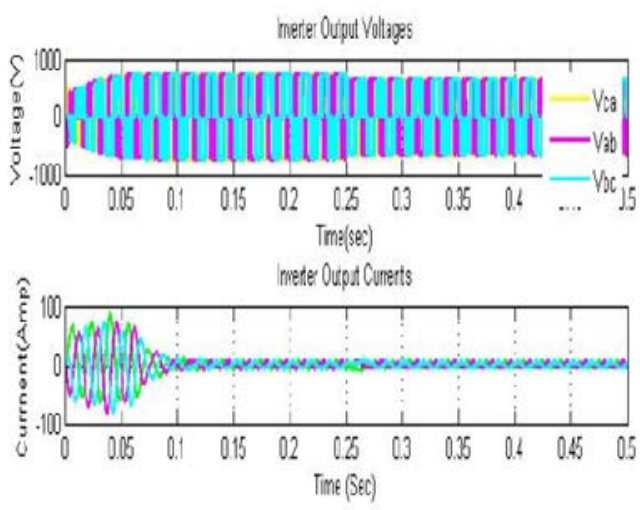

Fig. 12: Inverter output parameters

Fig. 11 depicts that SVPWM based control signals which are controlling the inverter switches in closed loop mode to get required speed, and produce output parameters of inverters are presented.

\section{CONCLUSION}

As the solar has significant potential among all the renewable energy resources, solar power modules should be installed in domestic and industries for electrification or various applications which are listed. Performance of inverter is improved with SVPWM. By utilizing solar powered system with SVPWM for IM speed control, losses can be reduced, power supply problems can be reduced, motor heating and stress can be reduced, increases efficiency, high saving in energy, low maintenance, long life and improves the process of control. Thus the developed model is robust and energy saving system.

\section{REFERENCES}

[1] W. Xiao, F.F. Edwin, G. Spagnuolo and J. Jatskevich, "Efficient Approaches for Modeling and Simulating Photovoltaic Power Systems", IEEE Journal of Photovoltaic, Vol. 3, No. 1, Pp. 500-508, 2013.

[2] T. Messo, J. Jokipii, J. Puukko and T. Suntio, "Determining the Value of DC-Link Capacitance to Ensure Stable Operation of a Three-Phase Photovoltaic Inverter”, IEEE Trans. power Electronics, Vol. 29, No. 2, Pp. 665-673, 2014.

[3] D.V.A.S. Ram and B.V. Ramana, "V/F speed control of SVPWM based Solar fed Induction Motor”, IJAIEM, Vol. 3, No. 11, 2014.

[4] Dr.T. Govindaraj and R.S. Sreema, "Simulation Modeling On Micro Solar Inverter and Pi Controller Based Induction Drive”, IJREAT, Vol. 1, No. 6, Pp. 01-12, 2014.

[5] K.R. Sasitharan and Dr.K. Ranjith Kumar, "Implementation of P\&O MPPT Quasi-Z-Source Inverter Fed Three-Phase Induction Motor”, The International Journal of Science \& Technoledge, Vol. 2, No. 13, Pp. 1318, 2014.

[6] K.B. Rohit, G.M. Karve and Khatri, "Solar Water Pumping System", International Journal of Emerging Technology and Advanced Engineering, Vol. 3, No. 7, Pp. 323-337, 2013.

[7] Dr.Rashmi, K.S. Rajesh, J. Manohar and C. Darshini, "Speed control of Induction Motor Using Push-Pull Converter and Three Phase SVPWM Inverter", International Journal of Innovative Research in Science, Engineering and Technology, Vol. 5, Special Issue 9, Pp. 733-738, 2016. 